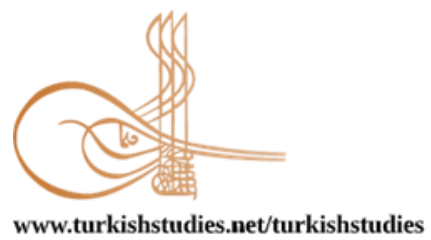

Turkish Studies

\title{
Okul Öncesi Dönem Çocuklarının Pandemi Sürecinde (COVID-19) Davranış Değişiklikleri ve Farkındalık Düzeylerinin Anne Görüşlerine Başvurularak İncelenmesi
}

\author{
Investigation of Behavioral Changes and Awareness Levels of Preschool Children in Pandemic \\ Process (COVID-19) by Applying to Mother's Opinions
}

\author{
Suna Tarkoçin* - Nurcan Alagöz ${ }^{* *}$ - Ebru Boğa ${ }^{* * *}$
}

\begin{abstract}
The purpose of this research is the investigation of behavioral changes and awareness levels of preschool children in the pandemic process (COVID-19) by referring to mothers' opinions. The research was carried out by using interview technique, which is one of the qualitative research methods. The sample of the study consists of 30 mothers who have 3-6 years old children who receive preschool education selected by the snowball sampling method. Before this study was carried out, Bingöl University Scientific Research and Publication Ethics Committee was consulted and the required ethics committee permission was obtained with the date and number of documents 13/05/2020-E.8499. In the research, "Personal Information Form" created by the researchers and "Interview Form" created by the researchers with the expert opinion were used as data collection tool. As a result of the research, it was detected that children have increased awareness of the disease after the pandemic, children generally know what COVID-19 is, families usually talk with their children after the pandemic, children perceive the virus as dangerous and interpret the virus in different ways. In addition to that the majority of mothers stated that their children did not have emotional and behavioral problems before the pandemic, but after the pandemic process; behaviors such as "anxiety, fear, aggressive / angry / furious behaviors, excessive mobility, sister-jealousy, parent-dependency" appeared in their children and it was also
\end{abstract}

\footnotetext{
* Öğretim Görevlisi, Bingöl Üniversitesi, Sağlık Hizmetleri Meslek Yüksek Okulu, Çocuk Bakımı ve Gençlik Hizmetleri Bölümü, Çocuk Gelișimi Programı

Lecturer, Bingöl Universty, Health Services Vocational School, Child Care and Youth Services Department, Child Development Program

ORCID 0000-0002-3380-2144

sunatarkocin@bingol.edu.tr

** Öğretim Görevlisi, Bingöl Üniversitesi, Sağlık Hizmetleri Meslek Yüksek Okulu, Çocuk Bakımı ve Gençlik Hizmetleri Bölümü, Çocuk Gelişimi Programı

Lecturer, Bingöl Universty, Health Services Vocational School, Child Care and Youth Services Department, Child Development Program

ORCID 0000-0002-1344-6760

nalagoz@bingol.edu.tr

**** Öğretim Görevlisi, Dicle Üniversitesi, Ergani Meslek Yüksek Okulu, Çocuk Bakımı ve Gençlik Hizmetleri Bölümü, Çocuk Gelişimi Programı

Lecturer, Dicle Universty, Ergani Vocational School, Child Care and Youth Services Department, Child Development Program

ORCID 0000-0001-9487-6123

ebru.boga@dicle.edu.tr

Cite as/ Atıf: Tarkoçin, S., Alagöz, N. \& Boğa, E. (2020). Okul öncesi dönem çocuklarının pandemi sürecinde (COVID-

19) davranış değişiklikleri ve farkındalık düzeylerinin anne görüşlerine başvurularak incelenmesi. Turkish Studies, 15(6), 1017-1036. https://dx.doi.org/10.7827/TurkishStudies.44338

Received/Geliş: 18 June/Haziran 2020

Accepted/Kabul: 15 October/Ekim 2020

Copyright $\mathbb{C}$ MDE, Turkey
} 
found that the mothers stated that the perception of healthy nutrition occurred in their children after the pandemic. In addition, it was shown that the sleep patterns of the children are disordered and irregular after the pandemic process. It was also shown that there is an increase in children's hand washing habits after the pandemic and the majority of children follow the 20 seconds rule while washing their hands, children use the communication tools a lot, are nervous about going out after the pandemic and they know the social distance rule, the time that mothers spend with their children and time to play with them increased after the pandemic process.

Structured Abstract: Introduction: Comprehensive events affecting societies also affect children in childhood, which is quite developmentally sensitive. Theorists like Bandura, Brofenbrenner and Vygotsky also see environmental factors such as family, school, group of friends and media with which the child interacts lifelong, as key points in the child's developmental process (Özmenteş and Adızel, 2017). In this context, everything that happens around the child directly or indirectly affects the developmental process and therefore, children are not indifferent to the pandemic process that affects the whole world. Apart from experiencing fear, uncertainties, physical and social isolation experiences, they remain separate from school for a long time. Understanding children's reactions and feelings is very important to meet their needs well (Jiao et al., 2020). Sometimes parents or other siblings who are overwhelmed by the COVID-19 crisis can trigger depression, anxiety, or other psychiatric disorders of the other emotionally sensitive child (Wagner, 2020). From this point of view, it is important to determine the behavioral changes and awareness levels that occur in children during the pandemic process.

In addition to studies showing that having fun in the media during the COVID-19 pandemic process is effective in reducing emotional and behavioral problems in children; Researches stating that children living in the pandemic process and in the pandemic region are in the risk group for post-traumatic stress disorder were also found (Imran et al., 2020; Jiao et al., 2020; Davico et al., 2020). In a study conducted in 320 children and adolescents aged 3-18 (168 girls and 142 boys) in Shaanxi Province, permitted by local authorities in the second week of February 2020; psychological and behavioral problems such as distraction, irritability and fear of asking about epidemics have been observed to be very common (Jiao et al., 2020).

Good knowledge of how to manage COVID-19 as a community; can be effective in reducing anxiety of healthcare professionals, families and children (Jiao et al., 2020; Sinha et al., 2020). Since the COVID-19 pandemic is an extraordinary and new condition, there are no studies examining children's awareness and knowledge levels of pandemic process stating that COVID-19 may cause stress and anxiety in children by closing schools and keeping children apart from their friends. In this study, it was aimed to investigate what kind of behavioral changes and awareness levels of preschool children show in the pandemic process (COVID19) by referring to the mothers' views. For this purpose, answers were sought for the following questions;

- How did the pandemic process (COVID-19) affect children's behavior?

- What is the level of awareness and knowledge of children about the COVID-19 outbreak?

Method: This study is a qualilative research based on descriptive analysis. Qualitative researches are described as researches in which qualitative data collection methods such as observation, interview and document analysis are used and qualitative process is followed to reveal perceptions and events in a realistic and holistic manner (Yıldırım vd.,2018). Descriptive analysis, which is used for data analysis in qualitative research and is carried out in order to present the obtained findings to the reader in on organized and interpreted form, enables the researcher to read the data, organize and digitize it (Dawson, 2009).

The study was conducted using structured in-depth interview technique, which is frequently used in qualitative research. In-depth interview technique; is a single-participant, direct and face-to-face research technique. The purpose of this technique is to reveal the beliefs, habits, feelings and attitudes of a particular subject during the interview and to understand the subject in depth (Okumuş, 2020). It is carried out in the form of collecting data from the relevant people within the scope of questions asked for answers in interview studies. Interview research has a very flexible structure (Büyüköztürk, 2016).

The sample of the study consists of 30 mothers who have 3-6 years old children who receive preschool education selected by the snowball sampling method. Before this study was carried out, Bingöl University Scientific Research and Publication Ethics Committee was consulted and the required ethics committee permission was obtained with the date and number of documents 13/05/2020-E.8499. In the research, "Personal 
Information Form" created by the researchers and "Interview Form" created by the researchers with the expert opinion were used as data collection tool. Due to the pandemic process, the data were collected online through video interviews with mothers. Mothers who did not have a video call were asked questions via home or mobile phone. The researchers recorded the answers they received from the mothers by asking the mothers one by one the questions in the personal information form and the interview form during the interviews. Accordingly, 30 mothers were interviewed between 14/05/2020 and 21/05/2020 for an average duration of 25 minutes, and data were collected. In the analysis of the data obtained as a result of the research, the MAXQDA PRO 2020 package program, that is used in qualitative research methods, was used.

Results and Discussion: When the findings regarding the responses of the mothers participating in the study to the disease awareness are examined; it is observed that children's awareness of the disease increases after the pandemic, children generally know what COVID-19 is, families usually talk with their children about the process after pandemia, children perceive the virus as dangerous and interpret the virus in different ways. The reason why children know so much about COVID-19 pandemic is due to the fact that The World Health Organization declared this as a pandemic and our country took many measures to prevent the epidemic process and children learned these measures from their parents, social environment, and mass media (WHO, 2020). Children who are constantly exposed to pandemic measures may perceive the pandemic process as a dangerous condition. Another research that emphasizes the importance of parents talking about the process with their children and supports the research result was conducted by Dalton et al., (2020). In that study, namely " Protecting children's psychology health through effective communication about COVID-19", they stated that talking about COVID-19 with children would prevent children from having unnecessary fear.

According to the findings obtained from the answers given to the questions about emotional / behavioral problems; the majority of mothers stated that their children did not have emotional and behavioral problems before the pandemic, but after the pandemic process; behaviors such as "anxiety, fear, aggressive / angry / furious behaviors, excessive mobility, sister-jealousy, parent-dependency" appeared in their children. Disruption of the routine life of children and families in the current epidemic can lead to different emotional and behavioral problems in children. The concept of disease has many negative effects on children and families. For this reason, families should spend this period with less stress and should not talk to their children in detail about the negative aspects of pandemic process unless necessary (Ercan et al.,, 2020; Er, 2006). Studies supporting this result have also been found in the literature. In a study of Jiao et al., (2020) named as "Emotional and behavioral disorders in children during the COVID-19 outbreak", it was determined that short temper, being glued to the family, distractibility and askophobia are the most common disorders in children after COVID-19. Similarly Davico et al., (2020) also detected in their study that children in the pandemic area are at risk for post-traumatic stress disorder. In the study of Sprang and Silman (2013); it was concluded that children isolated or quarantined in a health related disaster experience more post-traumatic stress disorder.

Considering other findings obtained as a result of the research; it was shown that the sleep patterns of the children are disordered and irregular after the pandemic process. It was also shown that there is an increase in children's hand washing habits after the pandemic and the majority of children follow the 20 seconds rule while washing their hands but some mothers have anxiety about developing obsessions in their children although mothers are generally satisfied with their children's hand washing behavior. The results obtained from this study show that the hand washing behavior of children is mostly caused by the virus. One of the biggest reasons for the disturbance of the sleep patterns of children may be due to the fact that families spend more time at home due to the pandemic, they carry out their work remotely, and that they themselves sleep late and get up late, and the children who go to kindergarten do not have school routines. The reason why children follow the 20 seconds rule in hand washing and they are aware of this fact is that one of the ways of transmission of COVID-19 is not washing the hands well and this fact is frequently repeated in mass media, social media and in the conversations of the families with their children about COVID-19 (Aslan, 2020).

Mothers stated that there was a feeding problem in 6 children before the pandemic, but it was observed that irregular feeding decreased after the pandemic and generally, children who were fed regularly before the pandemic were more interested in regular feeding after the pandemic. Mothers stated that the perception of healthy nutrition occurred in their children after pandemic process. One of the individual measures to combat COVID-19 is to strengthen the immune system (Aslan, 2020). Families telling their children about COVID19 , talking about their effects and how to protect themselves can cause children to care more about regular nutrition. 
When the answers given to the question of mass media usage before pandemic are examined; the majority of mothers stated that their children used the mass media before the pandemic, but there was a huge increase after the pandemic. Parents themselves also said that while they were using mass media, their children listened to pandemic broadcasts and were affected by these broadcasts. The reason for this result in the research may be the interruption of education due to pandemic and education through distance education systems. Many children and families may have started to use mass media more after the pandemic in order to participate in trainings with distance education systems. In addition, in a study by Jiao et al. (2020), it was stated that having fun time in the media is effective in reducing emotional and behavioral problems in children. Therefore, it may be aimed to reduce the emotional and behavioral problems of children by spending fun time in the media by increasing the use of mass media (medium) in the pandemic process.

Mothers also stated that their children are uneasy about going out after the pandemic and generally know the rule of social distance; often question why people are outside when they see some people outside through the balcony or glass, say that people who are outside make mistake and gets angry because of not being outside. Research results show that pandemic has a lot of negative effects on children's behavior and development. Disruptions in the daily routines of children can have negative consequences for children's wellbeing and development (TheAlliancefor Child Protection in Humanitarian Action, 2019). Imran et al., (2020) also stated in their study that closing schools and keeping children apart from their friends can cause stress and anxiety in children.

Finally, the mothers stated that the time they spent with their children and the time to play with their children increased after this pandemic process. It was concluded that the disease was mentioned in games and activities and that a mother said that her child was more aggressive in the activities. When these results are evaluated; it can be said that not going to school due to closed nurseries and kindergartens, and spending more time at home due to transition to remote working system, mothers have increased activity time with their children.

Conclusion and recommendations: When the findings obtained from the research are analyzed, it is seen that children are significantly affected by the pandemic process. It is important to know how a situation affecting the whole world has an impact on children, to determine how children will be supported developmentally in this process. In this direction;

- In future researches, the effects of globally and socially influential situations such as pandemics on children should be examined with qualitative and quantitative researches considering different variables,

- In returning to normal activities, it is recommended to evaluate the situation of children affected by the process and to provide necessary psychosocial support.,

- It is recommended that educators and families should observe the children's reactions in the epidemic process, have a positive attitude towards reducing stress and anxiety and be a model for a positive focus and motivation.,

- Keeping the negative impact of the pandemic process on children and families in mind; it is suggested to bring the psychosocial service studies to the fore.

Keywords: Preschool Education, COVID-19, Pandemic, Child, Behavioral Change.

Öz: $\mathrm{Bu}$ araştırmanın amacı; okul öncesi dönem çocuklarının pandemi sürecinde (COVID-19) davranış değişiklikleri ve farkındalık düzeylerinin anne görüşlerine başvurularak incelenmesidir. Araştırma nitel araştırma yöntemlerinden görüşme tekniği kullanılarak gerçekleştirilmiştir. Araştırmanın çalışma grubunu ise kartopu örnekleme yöntemiyle seçilmiş okul öncesi eğitim alan 3-6 yaş çocuğa sahip 30 anne oluşturmaktadır. Bu çalışma yapılmadan önce Bingöl Üniversitesi Bilimsel Araştırma ve Yayın Etiği Kurul'una başvurulmuş ve gerekli etik kurulu izni 13/05/2020-E.8499 evrak tarihi ve sayısı ile alınmıştır. Araştırmada veri toplama aracı olarak araştırmacılar tarafından oluşturulan "Kişisel Bilgi Formu" ve yine araştırmacılar tarafından uzman görüşü alınarak oluşturulan "Görüşme Formu” kullanılmıştır. Araştırma sonucunda elde edilen veriler betimsel istatistikler kullanılarak tablolar halinde yorumlanmıştır. Araştırma sonucunda, çocukların pandemi sonrasında hastalık farkındalıklarının arttığı, çocukların genellikle COVID-19'un ne olduğunu bildikleri, 
ailelerin genellikle pandemiden sonra çocukları ile süreci konuştukları, çocukların virüsü tehlikeli olarak algıladıkları ve farklı şekillerde virüsü yorumladıkları, annelerin çoğunluğu çocuklarında pandemi öncesinde duygusal ve davranışsal sorunların olmadığını, ancak pandemi sonrasında çocuklarında "kaygı, korku, agresif/öfkeli/saldırgan davranışlar, aşırı hareketlilik, kardeş kıskançlı̆̆ı, anne-babaya bağımlılık" gibi davranışların ortaya çıktığını, annelerin pandemi sonrasında çocuklarında sağlıklı beslenme algısının oluştuğunu belirtikleri saptanmıştır. Ayrıca çocukların pandemi sonrasında uyku düzenlerinin bozulduğu ve düzensiz olduğu; çocukların el yıkama alışkanlıklarında pandemi sonrası artış olduğu ve çocukların çoğunluğunun 20 saniye kuralını ellerini yıkarken uyguladığı, pandemiden sonra çocukların kitle iletişim araçlarını çok fazla kullandıkları, çocukların pandemi sonrasında dışarı çıkma konusunda tedirginlik yaşadıkları ve sosyal mesafe kuralını bildikleri sonucuna varılmıştır.

Anahtar Kelimeler: Okul Öncesi Eğitim, COVID-19, Pandemi, Davranış değişikliği, Farkındalık, Çocuk.

\section{Giriş}

Koronavirüs, hayvanlarda veya insanlarda hastalığa neden olabilecek büyük bir virüs ailesidir. İnsanlarda, birkaç koronavirüsün soğuk algınlı̆̆ 1 gibi hafif bir hastalıktan Orta Doğu Solunum Sendromu (MERS) ve Şiddetli Akut Solunum Sendromu (SARS) gibi daha ciddi hastalıklara kadar solunum yolu enfeksiyonlarına neden olduğu bilinmektedir. En son keşfedilen koronavirüsün COVID-19 hastalığına neden olduğu belirlenmiştir. COVID-19 2020 yılında küresel olarak birçok ülkeyi etkileyen bir salgın haline gelmiştir. COVID-19'un en yaygın semptomları ateş, kuru öksürük ve yorgunluktur. Bazı hastalarda ağrı, burun tıkanıklığı, boğaz ağrısı veya ishal olabilir. COVID-19'a yakalanan her 5 kişiden yaklaşık 1'i hastalığı ağır geçirmekte ve nefes almakta güçlük çekmektedir. Bazı insanlar enfekte olmasına rağmen hastalığın sadece çok hafif semptomlarını göstermektedir. Virüs ile enfekte olanların \% 80'i hastane tedavisine ihtiyaç duymadan iyileşebilmektedir. Çok hafif COVID-19 semptomları olan insanlar bile virüsü bulaştırabilmektedir. COVID-19 öksürme, hapşırma veya konuşma sırasında atılan küçük damlacıkların yayılması yoluyla kişiden kişiye bulaşmaktadır. Virüs bulaşmış bir kişiyle aynı ortamda nefes alınması durumunda yayılan damlacıkların etkisiyle COVID-19 bulaşabilir. Bu yüzden diğer insanlardan en az 1 metre (3 adım) uzakta kalmak önemlidir. Ayrıca hastalık damlacık yoluyla kişilerin etrafindaki yüzey ya da nesnelere tutunabilir ve kişilerin bu nesnelere veya yüzeylere, ardından da gözlerine, burnuna veya ağzına dokunarak enfekte olmasına yol açabilir. Bu yüzden ellerin düzenli olarak sabun ve su ile yıkanması veya alkol bazlı el dezenfektanlarının kullanılması önemli görülmektedir (WHO, 2020).

Hastalığın fiziksel temas, solunum yolu vb. yollarla çok hızlı bir şekilde bulaşarak yayılmasın sonucunda enfekte olan insan sayısının hızla artırması, insan hayatı açısından son derece tehlikeli olması, büyük bir risk teşkil etmesi ve birçok ülkede görülmesi sebebiyle Dünya Sağlık Örgütü tarafından pandemi ilan edilmiştir. Pandemi TDK (2020) tarafından "Aynı zamanda birden fazla bölge, ülke veya kıtadaki toplulukları etkileyen çok yaygın hastalık" olarak tanımlanmıştır. Virüse karşı mücadelede hastalığın sonuçlarını hafifletmek ve popülasyondaki yüksek riskli grupları korumak için çeşitli stratejiler uygulanmaktadır. Genel olarak, çoğu ülkede uygulanmakta olan hijyen ve uzaklaştırma stratejileri, ülkelerdeki sağlık sistemlerinin çökmesini engelleyerek enfeksiyon oranını yavaşlatmayı amaçlamaktadır (Witt vd, 2020).

Araştırmalar, çocukların ve ergenlerin diğer yaş gruplarında olduğu gibi enfekte olma olasılıklarının yüksek olduğunu ve hastalığı yayabileceğini göstermektedir (WHO, 2020). Bu nedenle çocukların ve gençlerin kişisel hijyen, izolasyon, karantina ve fiziksel mesafe kurallarına uymaları çok önemlidir. Çünkü bu yaş guruplarındaki sağlıklı bireylerin hastalığı daha hafif semptomlarla yenebilmelerine karşın, risk guruplarındaki bireylere bulaştırma ihtimalleri yüksektir. Çin'de Ocak ve Şubat 2020 tarihleri arasında yaşları 1 ve 18 arasında değişen COVID-19 tespit edilen 2.143 çocuk incelenmiştir. Tüm çocukların ortalama yaşı 7 olarak tespit edilmiş̧ir. Cinsiyet açısından anlamlı bir fark görülmemekle birlikte hastaların \%56.6'sı erkektir. Bu çalışma 1-18 yaş arasındaki tüm çocukların COVID-19'a duyarlı olduğunu göstermiştir (Dong vd. 2020). 
Çocuklar COVID-19 salgınının etkilerine karşı kayıtsız değildir. Korkular, belirsizlikler, fiziksel ve sosyal izolasyon deneyimleri yaşamalarının yanı sıra, okuldan uzun süre ayrı kalmaktadırlar. Çocukların tepkilerini ve duygularını doğru anlamak, onların ihtiyaçlarını iyi bir şekilde karşılamak için çok önemlidir (Jiao vd. 2020). COVID-19 nedeniyle gelişen yeni yaşam düzeni, çocuk ve ergenlerin depresyon ve anksiyete veya hiperaktivite belirtileri göstermelerine neden olabilir. Majör depresyon ve anksiyete bozuklukları geliştiren veya mevcut bir psikiyatrik bozukluğu şiddetlendiren ilaç veya kanıta dayalı psikoterapi gerektiren gençler olabilmektedir. Bazen de COVID-19 krizinden bunalan ebeveynler ya da diğer kardeşler, duygusal yönden daha hassas olan diğer çocuğun depresyonunu, kaygısını veya diğer psikiyatrik bozukluklarını tetikleyebilmektedir (Wagner, 2020). Çocuklar yaşadıkları kaygıyı daha tipik olarak ağrılı, üzücü veya endişeli yanıtlarla içselleştirmelerinin tersine, dışa vurma veya tartışma gibi dışsallaştırıcı davranışlarda da gösterebilirler (Dalton vd. 2020). Şubat 2020'nin ikinci haftasında yerel yetkililer tarafından izin verilen Shaanxi Eyaletinde 3-18 yaş arası 320 çocuk ve ergen (168 kız ve 142 erkek) arasında yapılan bir çalışmada, dikkat dağınıklığı, sinirlilik ve salgın hakkında soru sorma korkusu gibi psikolojik ve davranışsal sorunların çok yaygın yaşandığı görülmüştür (Jiao vd. 2020).

Gelişimsel açıdan hassas sayılan çocukluk ve ergenlik döneminde, pandemi sürecinin iyi yönetilmesi gerekmektedir. Ayrıca bu dönemde başlıca akımlar ve sosyal medya, sosyal mesafe ve izolasyonun uygulandığı pandemi sürecinde, insanları birleştirme ve bilgi paylaşımı oldukça önemlidir. Halk sağlığı mesajları, moral yükseltici hikayeler, halk tarafından oluşturulan ipuçları ve fikirler dahil olmak üzere, bilgileri bir popülasyona benzeri görülmemiş bir oranda yayabilmenin büyük avantajları vardır. Ancak bu hızlı bilgi paylaşımı, yanlış bilgilendirme riskini ortaya çıkarabilir. Sosyal medyanın doğası gereği, politik ve kişisel bakış açıları halk sağlığı çabalarını zayıflatarak karışıklığa neden olabilir. Raporlar yayınlanmadan son dakika haberlerine ayak uydurma baskısı, gerçeklerin bütünlüğünde ve kontrolünde bir azalmaya yol açabilir. Bu nedenle COVID-19'un bir toplum olarak nasıl yönetileceğini iyi bilmek sağlı çalışanları, aileler ve çocukların kaygı durumunu azaltmakta etkili olabilir (Sinha vd. 2020).

Pandemi sürecinde sosyal ve duygusal anlamda etkileri bulunan bir diğer önemli nokta da karantina sürecidir. Türkiye'de ilk karantina önlemleri 65 yaş üstü ve 20 yaş altı için uygulanmaya başlanmıştır. Yaşlıların ve daha büyük çocukların kişisel hijyen, karantina, sosyal izolasyon ve fiziksel mesafe gibi terimleri anlamaları ve yeni yaşam düzenine uyum sağlamalarının daha kolay olmasına karşın; okul öncesi dönem çocuklarının yaşları ve zihinsel gelişimleri itibarı ile bunlara nasıl anlamlar yükledikleri merak konusudur. Nitekim bilişsel gelişim alanında önemli çalışmaları bulunan Piaget, 2-6 yaş grubunda bulunan çocukları "işlem öncesi dönem" başlığında değerlendirmektedir. Bu dönemde çocuklar görünüş̧e göre yorum yapmaktadır ve yorumlar mantık dışıdır. Zihinsel tasarımlar kurulmasına rağmen bilgi sistemli bir şekilde işlenmemektedir. Çocuklar durumu sadece bir yönüyle ele almaktadırlar (Onur, 2015). Durumlara tek bir açıdan bakmanın temelinde ise benmerkezcilik bulunmaktadır. Piaget (2019), benmerkezciliği mantığın kesinleşmesi ve nesnelleşmesi önünde en büyük engel olarak yorumlamaktadır. Dolayısıyla benmerkezci düşünme sistemiyle hareket eden ve soyut düşünme becerilerini henüz kazanmamış olan okul öncesi dönem çocuklarının karantina sürecini anlamlandırabilmesi oldukça zordur.

Okul öncesi çocuğu dönem itibarıyla oyun çocuğudur. Bu dönemde çocukların ruhsal, sosyal, motor ve zihinsel becerilerini kazandıkları faaliyetlere yer verilmektedir. Günümüzde yaşanan salgın nedeniyle çocukların günlük rutinlerinin değişmesi; onları ruhsal, sosyal, motor ve zihinsel gelişimleri bakımından sekteye uğratabilmektedir. Bu durum çocukların zeminde var olan kayg1, korku, saplantı, mükemmeliyetçilik gibi bazı sorunlarının ortaya çıkmasına ya da farklı psikiyatrik problemlerin görülmesine zemin hazırlayabilmektedir. Bu dönemde ebeveynlerin abartıl1 davranışlar göstermeleri çocukların ruhsal olarak etkilenmesine sebep olmaktadır. Ebeveynlerin çocuklar için yeni olan bakteri, mikrop, virüs gibi kavramları doğru şekilde anlatmaları ve çocukların belirsizlik nedeniyle yaşadıkları kaygı durumlarını olabildiğince azaltacak yaşlarına uygun bilimsel 
bilgi sunmaları önemlidir (Ercan vd. 2020). Ebeveynler pandemi ve sonuçlarını çocuklarına açıklamak, bu belirsiz zamanlarda ailedeki herkese eşlik eden korku ve kaygıyı yöneterek kontrol altına alma rolünü üstlenmelidir (Witt vd., 2020).

$\mathrm{Bu}$ araştırmada okul öncesi dönem çocuklarının pandemi sürecinde (COVID-19) ne tür davranış değişikleri gösterdikleri ve farkındalık düzeylerinin anne görüşlerine başvurularak incelenmesi amaçlanmaktadır. Bu amaç doğrultusunda şu sorulara cevap aranmıştır;

- $\quad$ Pandemi süreci (COVID-19) çocukların davranışlarını nasıl etkilemiştir?

- Çocukların COVID-19 salgını hakkındaki farkındalık ve bilgi düzeyleri nedir?

\section{Araştırmanın modeli}

$\mathrm{Bu}$ çalışma betimsel analize dayandırılarak gerçekleştirilmiş nitel bir araştırmadır. Nitel araştırmalar; "gözlem, görüşme ve doküman analizi gibi nitel veri toplama yöntemlerinin kullanıldığı, algıların ve olayların doğal ortamda gerçekçi ve bütüncül bir biçimde ortaya konmasına yönelik nitel bir sürecin izlendiği araştırmalar” olarak tanımlanmaktadır (Yıldırım vd., 2018). Nitel araştırmalarda veri analizi amacıyla kullanılan; elde edilen bulguların düzenlenmiş ve yorumlanmış bir biçimde okucuyuya sunulması amacıyla gerçekleștirilen betimsel analiz ise, araştırmacının verileri okumasını, düzenlemesini ve sayısallaştırmasını sağlamaktadır (Dawson, 2009). Çalışma nitel araştırmalarda sıkça başvurulan yapılandırılmış derinlemesine görüşme tekniği kullanılarak yürütülmüsstür. Derinlemesine görüşme tekniği; tek katıllmcıll, doğrudan ve yüz yüze yapılan bir araştırma tekniğidir. Bu tekniğin amacı görüşme sırasında belirli bir konuya ait inançları, alışkanlıkları, duygu ve tutumları açığa çıkarmak ve konuyu derinlemesine anlamaktır (Okumuş, 2020). Görüşme araştırmalarında cevap aranan sorular kapsamında ilgili kişilerden veri toplama şeklinde yürütülür. Görüşme araştırmaları oldukça esnek bir yapıya sahiptir (Büyüköztürk, 2016).

Görüşme araştırmaları kullanılan verilerin özelliklerine ve kaynakların ulaşılabilirliğine göre farklı şekillerde yürütülebilir. $\mathrm{Bu}$ şekillerden biri olan yapılandırılmış görüşme tekniğinde araştırmacı tarafından önceden hazırlanmış belli bir sıraya sahip sorular vardır. Bu yöntem verilerin hızlı bir şekilde kodlanması, analiz ve ölçümlerin kolaylıkla yapılması ve ardından da araştırmanın kapsamlı bir şekilde karşılaştırılmasına imkan sağlamaktadır (Büyüköztürk, 2016).

\section{Çalıșma grubu}

Araştırmanın çalışma grubunu kartopu örnekleme yöntemiyle seçilmiş okul öncesi eğitim alan 3-6 yaş çocuğa sahip 30 anne oluşturmaktadır. Kartopu örneklemede araştırmaya gönüllü şekilde katılan her katılımcıdan, katılmaya istekli olan ve önceden belirlenen özellikleri taşıyan en az bir kişiyi belirlemeleri istenmektedir (Johnson, 2014). Çalışma grubuna ait demografik bilgiler Tablo 1 ve Tablo 2'de yer almaktadır. 
Tablo 1: Çalışma Grubundaki Çocuklara Ait Demografik Bilgiler

\begin{tabular}{lccc} 
& & $\mathrm{f}$ & $\%$ \\
\hline Yaş & 6 yaş & 13 & 43,33 \\
& 5 yaş & 11 & 36,67 \\
& 4 yaş & 6 & 20,00 \\
\hline Toplam & & 30 & $\% 100$ \\
\hline Cinsiyet & Erkek & 17 & 56,67 \\
& Kız & 13 & 43,33 \\
\hline Toplam & & 30 & $\% 100$ \\
\hline Ailedeki & Bir çocuk & 15 & 50,00 \\
Çocuk & İki çocuk & 13 & 43,33 \\
Sayis1 & Üç çocuk & 2 & 6,67 \\
\hline Toplam & & 30 & $\% 100$ \\
\hline Doğum & İlk çocuk & 23 & 76,67 \\
Sirası & Ortanca & 5 & 16,67 \\
& Son çocuk & 2 & 6,67 \\
\hline Toplam & & 30 & $\% 100$ \\
\hline Kuruma & Bir yıl & 13 & 43,33 \\
Devam & İki yll & 13 & 43,33 \\
Etme & Ǘç yıl & 4 & 13,33 \\
\hline Toplam & & 30 & $\% 100$ \\
\hline
\end{tabular}

Tablo 1'de katılımcıların yaş, cinsiyet, ailedeki çocuk sayısı, doğum sırası ve okul öncesi kuruma devam etme süresine yönelik bilgiler yer almaktadır. 6 yaş grubundan 13 çocuk, 5 yaş grubundan 11 çocuk ve 4 yaş grubundan 6 çocuk çalışmada yer almıştır. Cinsiyet dağılımına bakıldığında 17 kız, 13 erkek olduğu görülmektedir. Ailedeki çocuk sayısı ise; bir çocuk 15, iki çocuk 13, üç çocuk 2 şeklinde bir dağılım göstermektedir. Doğum sırası incelendiğinde ilk çocuk 23, ortanca çocuk 2 ve son çocuk sayıs1 5'tir. Son olarak okul öncesi kuruma devam etme süresine bakıldığında araştırmaya katılan çocuklardan 13 tanesi ilk yılında iken, 13 tanesi de ikinci yılındadır. 4 çocuk ise okul öncesi eğitim kurumuna 3 yıldır devam etmektedir. 
Tablo 2: Çalışma Grubundaki Ebeveynlere Ait Sosyo-Demografik Bilgiler

\begin{tabular}{lccc}
\hline & & f & $\%$ \\
\hline Anne & Üniversite ve üstü & 22 & 73,33 \\
Öğrenim & Lise & 3 & 10,00 \\
Durumu & İlkokul ve ortaokul & 5 & 16,67 \\
\hline Toplam & & 30 & $\% 100$ \\
\hline Baba & Üniversite ve üstü & 25 & 83,33 \\
Öğrenim & Lise & 1 & 3,33 \\
Durumu & İlkokul ve ortaokul & 4 & 13,33 \\
\hline Toplam & & 30 & $\% 100$ \\
\hline Anne & Memur & 18 & 60,33 \\
Meslek & Çalışmiyor & 10 & 33,3 \\
Bilgileri & İşçi & 2 & 6,67 \\
\hline Toplam & & 30 & $\% 100$ \\
\hline Baba & Memur & 17 & 56,67 \\
Meslek & Serbest & 8 & 26,67 \\
Bilgileri & İşçi & 5 & 16,67 \\
\hline Aile & Yüksek & 19 & 63,33 \\
Gelir & Orta & 6 & 20,00 \\
Düzeyi & Düşük & 5 & 16,67 \\
\hline Toplam & & 30 & $\% 100$ \\
\hline
\end{tabular}

Tablo 2'de anne ve baba öğrenim durumu, anne ve baba meslek bilgileri ile aile gelir düzeyine yönelik bilgiler yer almaktadır. Bilgiler incelendiğinde anne öğrenim durumu üniversite ve üstü olan 22 kişi, ilkokul ve ortaokul mezunu olan 5 kişi ve lise mezunu olan 3 kişi çalışmaya katılmıştır. Baba öğrenim durumuna bakıldığında üniversite ve üstü 25 kişi, ilkokul ve ortaokul mezunu 4 kişi ve lise mezunu 1 kişi olduğu görülmektedir. Meslek bilgileri incelendiğinde anne meslek grupları 18 kişi memur, 10 ev hanımı, 2 işçi olduğu görülmektedir. Baba meslek gruplanı ise 17 memur, 8 serbest ve 5 işçi şeklinde dağ 1 lım göstermektedir. Son olarak aile gelir düzeyine yönelik bilgilere bakıldığında 19 yüksek, 6 orta ve 5 düşük olduğu görülmektedir.

\section{Veri Toplama Araçları}

Araştırmada veri toplama aracı olarak araştırmacılar tarafından oluşturulan "Kişisel Bilgi Formu" ve yine araştırmacılar tarafindan oluşturulmuş ve uzman görüşü alınmış "Görüşme Formu" kullanılmıştır.

Kişisel Bilgi Formu çocukların yaş, cinsiyet, anne - baba eğitim durumu, kardeş sayısı ve ailenin ekonomik durumunu öğrenmeyi amaçlayan sorulardan oluşmaktadır.

Görüşme Formu ise, COVID-19 pandemisinin öncesi ve sonrası değerlendirilerek çocuklarda meydana gelen davranış değişikliklerine ve ebeveyn-çocuk ilişkisine yönelik sorulardan oluşmaktadır. Görüşme formunda yer alan sorular ana başlıklar ve alt başlıklar halinde şu şekildedir:

1. Davranış değişikliğine yönelik sorular

1.1.El yıkama alışkanlığı

- Çocuğun el yıkama sıklığı ve süresi

-Çocuğun ellerini yıkarken 20 saniye kuralına uyma durumu

-Çocuğun el yıkama davranışında meydana gelen artışı etkileyen sebepler

-Çocuğun el yıkama davranışında ortaya çıkan artışa karşı ailenin tutumu

1.2.Uyku düzeni

-Çocuğun geceleri uyanma durumu

-Çocuğun geceleri alt sslatma ya da uykuda konuşma-bağırma durumu 
1.3.Beslenme alışkanlıkları

-Çocuğun pandemi nedeniyle sağlıklı beslenme algısı oluşturma durumu

1.4.Duygusal/Davranışsal durum

-Çocuğun kaygı düzeyi

-Çocukta gözlemlenen diğer duygusal/davranışsal sorunlar

1.5.Hastalık farkındalığ 1

-Çocuğun COVID-19 pandemisini bilme ve tanıma durumu

-Çocuğun virüsü tanımlama ve tasvir etme durumu

-Çocuk ile pandemiden sonraki süreç hakkında konuşma durumu

2. Ebeveyn çocuk ilişkisine yönelik sorular

2.1.Çocukla bereber evde geçirilen zaman

-Evde çocukla beraber boyama/resim/çizim ya da proje etkinlikleri yapma sıklığı

-Çocukla evde oyun oynama sıklığ 1

-Çocuğun evdeki etkinliklerde ya da oyunlarda pandemiden dolayı niteliksel bir değişim yaşaması durumu

2.2. Çocuğun dişarı çikma tutumu

-Çocuğun dişar1/parka/bahçeye çıkmak istemesi durumu

-Çocuğun balkondan ya da pencereden dışarıda gördüğü insanlara verdiği tepki

-Çocuğun sosyal mesafe kavramına dair tutumu ve bakış açısı

-Çocuğun pandemiden sonra tekrar dişarı çıkmaya dair tutumu

2.3.Çocuğun televizyon/tablet/telefon gibi kitle iletişim araçları ile geçirdiği zaman

-Evde sürekli pandemi ile ilgili yayınların takip edilmesi veya pandemi ile ilgili sürekli konuşulması durumu

-Çocuğun pandemi ile ilgili yayınları izlemesi ve etkilenmesi durumu

-Evde sürekli pandemi ile ilgili yayınların izlenmesi veya pandemi ile ilgili konuşulmasına karşı çocuğun ilgisi.

\section{Veri Toplama İşlemleri}

Araştırma, pandemi nedeniyle annelerle görüntülü görüşme programları aracılığıyla online ortamda gerçekleştirilmiştir. Görüntülü arama imkanı olmayan annelere ev ya da cep telefonu aracılığıyla sorular sorulmuştur. Araştırmacılar, annelere görüşmeler sırasında Kişisel Bilgi Formu ve Görüşme Formunda yer alan soruları tek tek sorarak annelerden aldıkları cevapları kaydetmişlerdir. Her görüşme ortalama 25 dakika sürmüştür ve annelerin soruları içtenlikle doğru bir şekilde cevapladıkları varsayılmıştır. Bu doğrultuda 30 anne ile 14/05/2020 ve 21/05/2020 tarihleri arasında ortalama 25 dakika süren görüşmeler yapılarak veriler toplanmıştır.

\section{Verilerin Analizi}

Araştırmanın verilerinin analizinde nitel araştırma yöntemlerinde kullanılan MAXQDA PRO 2020 paket programı kullanılmıştır. Araştırmacılar tarafından annelerden alınan görüşme formaları tek tek kodlamalar yapılarak MAXQDA programına veri girişi yapılmıştır. Analiz sonuçları bulgular bölümünde verilmiştir.

\section{Çalışmanın Etik Yönü}

Bu çalışma yapılmadan önce Bingöl Üniversitesi Bilimsel Araştırma ve Yayın Etiği Kurul'una başvurulmuş ve gerekli etik kurulu izni 13/05/2020-E.8499 evrak tarihi ve sayısı ile alınmıştır. 


\section{Bulgular ve Yorum} almaktadır.

$\mathrm{Bu}$ bölümde araştırma verilerinin analiz edilmesi sonucunda elde edilen bulgular yer

Tablo 3: 3-6 Yaş Çocukların COVID-19 Hastalığına İlişkin Farkındalıkları

\begin{tabular}{|c|c|c|c|}
\hline & & $\mathrm{f}$ & $\%$ \\
\hline Pandemi & Farkındalık var & 26 & 86,67 \\
\hline Öncesi & Farkındalık yok & 4 & 13,33 \\
\hline Toplam & & 30 & $\% 100$ \\
\hline \multirow{10}{*}{$\begin{array}{l}\text { Pandemi } \\
\text { Sonras1 }\end{array}$} & Farkındalık arttı & 23 & 86.67 \\
\hline & Değișim yok & 6 & 20,00 \\
\hline & COVID-19'un ne & 26 & 86,67 \\
\hline & $\begin{array}{l}\text { olduğunu biliyor } \\
\text { Pandemiden sonraki }\end{array}$ & & \\
\hline & $\begin{array}{l}\text { süreç hakkında } \\
\text { konuşuluyor }\end{array}$ & 30 & 100,00 \\
\hline & $\begin{array}{l}\text { Virüsün hastalık } \\
\text { sebebi olduğunu } \\
\text { söylüyor }\end{array}$ & 17 & 56,67 \\
\hline & $\begin{array}{l}\text { Virüsün tehlikeli } \\
\text { olduğunu söylüyor }\end{array}$ & 6 & 20,00 \\
\hline & $\begin{array}{l}\text { Virüsün küçük ve } \\
\text { canlı bir şey } \\
\text { olduğunu söylüyor }\end{array}$ & 2 & 6,67 \\
\hline & $\begin{array}{l}\text { Virüsün dışarırda } \\
\text { dolaşan bir şey } \\
\text { olduğunu söylüyor }\end{array}$ & 4 & 13,33 \\
\hline & $\begin{array}{l}\text { COVID-19'un ne } \\
\text { olduğunu bilmiyor }\end{array}$ & 4 & 13,33 \\
\hline
\end{tabular}

Tablo 3 'te görüşme formunda yer alan hastalık farkındalığı sorularına verilen cevapların kod matris tarayıcısından elde edilen dağılımları verilmiştir. Buna göre 26 anne pandemiden önce farkındalık olduğunu, 4 anne ise farkındalık olmadığını belirtmiştir. Pandemi sonrasında ise; 23 anne pandemiden sonra hastalık farkındalığının arttığını, 26 anne çocuğun COVID-19'un ne olduğunu bildiğini, 4 anne ise bilmediğini, 6 anne değişiklik olmadığını belirtirmiştir. Çocukların virüs ile ilgili yorumlarına bakıldığında; 6 çocuk virüsün tehlikeli olduğunu, 2 çocuk tehlikeli ve küçük olduğunu, 4 çocuk virüsün dışarıda dolaşan bir şey olduğunu, 17 çocuk ise virüsün hastalık sebebi olduğunu ifade etmiştir. 
Tablo 4: 3-6 Yaş Çocukların Duygusal/Davranışsal Sorunları

\begin{tabular}{llcc} 
& & $\mathrm{f}$ & $\%$ \\
\hline Pandemi & Sorun var & 3 & 90,00 \\
Öcesi & Sorun yok & 27 & 90,00 \\
\hline Toplam & & 30 & $\% 100$ \\
\hline \multirow{2}{*}{ Sonrası } & Değişiklik yok & 9 & 30,00 \\
& Kaygllı & 11 & 36,67 \\
& Agresif/Öfkeli/ & 7 & 23,33 \\
& Saldırgan & & \\
& Daha duygusal ve & 7 & 23,33 \\
& çabuk ağliyor & & \\
& Daha çok korkuyor & 4 & 13,33 \\
& Kardeş kıskançlığı & 1 & 3,33 \\
& Anne babaya & 1 & 3,33 \\
& bağımlılık & & 3,33 \\
& Aşırı hareketlilik & 1 & 3,33 \\
& Durgunluk & 1 &
\end{tabular}

Tablo 4'te 3-6 yaş çocukların duygusal/davranışsal sorunları ile ilgili bilgiler incelendiğinde; pandemi öncesi 27 çocukta sorun olmadığı 3 çocukta ise sorun olduğu saptanmıştır. Pandemi sonrası ise; 9 çocukta değişiklik olmadığı, 11 çocukta kaygı, 7 çocukta agresif/öfkeli/saldırgan tavırlar, 7 çocukta daha duygusal olma ve daha çabuk ağlama, 4 çocukta korku, 1 çocukta kardeş kıskançlığı, 1 çocukta anne babaya bağımlılık, 1 çocukta aşırı hareketlilik, 1 çocukta ise durgunluk oluştuğu belirtilmiştir.

Tablo 5: 3-6 Yaş Çocukların Beslenme Alışkanlıkları

\begin{tabular}{llcc} 
& & f & $\%$ \\
\hline Pandemi & Düzenli & 24 & 80,00 \\
& $\begin{array}{l}\text { Beslenme sorunları } \\
\text { var }\end{array}$ & 6 & 20,00 \\
\hline Toplam & & 30 & $\% 100$ \\
\hline \multirow{2}{*}{ Pandemi } & Değişiklik yok & 17 & 56,67 \\
Sonrası & Daha düzenli & 10 & 33,33 \\
& beslenme & & \\
& $\begin{array}{l}\text { Sağlıklı beslenme } \\
\text { algısı oluştu }\end{array}$ & 8 & 26,67 \\
& Düzensiz Beslenme & 3 & 10,00 \\
\hline
\end{tabular}

Tablo 5'te 3-6 yaş çocukların beslenme alışkanlıkları ile ilgili veriler yer almaktadır. 24 anne pandemi öncesi çocukta düzenli beslenme alışkanlığı olduğunu belirtirken, 6 anne beslenme sorunları olduğunu belirtmiştir. Pandemi sonrası ise 17 anne değişiklik olmadığını, 10 anne daha düzenli beslenme alışkanlığı oluştuğunu, 8 anne sağlıklı beslenme algısı oluştuğunu, 3 anne ise düzensiz beslenme oluştuğunu ifade etmiştir. 
Tablo 6: 3-6 Yaş Çocukların Uyku Düzeni

\begin{tabular}{llcc} 
& & f & $\%$ \\
\hline Pandemi & Düzenli & 28 & 93,33 \\
Öncesi & Düzensiz & 2 & 6,67 \\
\hline Toplam & & 30 & $\% 100$ \\
\hline \multirow{2}{*}{ Pandemi } & Düzenli & 16 & 53,33 \\
sonrasi & $\begin{array}{l}\text { Alt 1slatma ve } \\
\text { uykuda konuşma yok }\end{array}$ & 24 & 80,00 \\
& $\begin{array}{l}\text { Geç uyuyup geç } \\
\text { uyanma }\end{array}$ & 14 & 46,67 \\
& $\begin{array}{l}\text { Geceleri uyanma } \\
\text { nadiren } \\
\text { Anne babayla uyuma }\end{array}$ & 2 & 6,67 \\
& $\begin{array}{l}\text { isteği } \\
\text { Alt 1slatma ve } \\
\text { uykuda konuşma } \\
\text { (bazen) }\end{array}$ & 5 & 16,67 \\
\hline
\end{tabular}

Tablo 6'da 3-6 yaş çocukların uyku düzeni ile ilgili veriler incelendiğinde; pandemi öncesi 28 çocukta düzenli uyku alışkanlığı olduğu, 2 çocukta ise düzensiz uyku alışkanlığı olduğu görülmektedir. Pandemi sonrasına bakıldığında 16 çocukta uyku düzeni olduğu, 24 çocukta alt 1slatma ve uykuda konuşma olmadığ 1,14 çocukta geç uyuyup geç uyanma olduğu, 2 çocukta nadiren geceleri uyanma olduğu, 5 çocukta anne babayla uyuma isteği oluştuğu ve 4 çocukta bazen alt 1slatma ve uykuda konuşma olduğu saptanmıştır.

Tablo 7: 3-6 Yaş Çocukların El Yıkama Alışkanlığı

\begin{tabular}{|c|c|c|c|}
\hline & & $\mathrm{f}$ & $\%$ \\
\hline \multirow{3}{*}{$\begin{array}{l}\text { Pandemi } \\
\text { Öncesi }\end{array}$} & Normal & 25 & 83,33 \\
\hline & $\mathrm{Az}$ & 3 & 10,00 \\
\hline & Çok & 2 & 6,67 \\
\hline \multicolumn{2}{|l|}{ Toplam } & 30 & $\% 100$ \\
\hline \multirow{4}{*}{$\begin{array}{l}\text { Pandemi } \\
\text { sonrası }\end{array}$} & Çok sık & 25 & 83,33 \\
\hline & Normal & 5 & 16,67 \\
\hline & $\begin{array}{l}20 \text { saniye kuralını } \\
\text { biliyor ve uyguluyor }\end{array}$ & 25 & 83,33 \\
\hline & $\begin{array}{l}20 \text { saniye kuralını } \\
\text { biliyor ama } \\
\text { uygulamıyor }\end{array}$ & 4 & 13,33 \\
\hline \multirow{5}{*}{$\begin{array}{l}\text { El } \\
\text { Yıkama } \\
\text { Artış } \\
\text { Sebebi }\end{array}$} & Virüs & 15 & 50,00 \\
\hline & Yayınlar & 10 & 33,33 \\
\hline & Okulda Öğrenme & 2 & 6,67 \\
\hline & Aile Bilgilendirmesi & 2 & 6,67 \\
\hline & Ailede çok olması & 11 & 36,67 \\
\hline \multirow{4}{*}{$\begin{array}{l}\text { Annenin } \\
\text { tutumu }\end{array}$} & Memnun & 16 & 53,33 \\
\hline & Normal karşılama & 6 & 20,00 \\
\hline & $\begin{array}{l}\text { Paniklediği için } \\
\text { üzülme }\end{array}$ & 1 & 3,33 \\
\hline & $\begin{array}{c}\text { Obsesyon oluşma } \\
\text { kaygisı }\end{array}$ & 3 & 10,00 \\
\hline
\end{tabular}


Tablo 7'de 3-6 yaş çocukların el yıkama alışkanlığına yönelik bilgilere yer verilmiştir. Buna göre 25 anne pandemi öncesi çocukta el yıkama alışkanlığının normal olduğunu, 3 anne el yıkamanın az olduğunu, 2 anne ise el yıkamanın çok olduğunu belirtmiştir. Pandemi sonrasına bakıldığında; 25 anne çok sık, 5 anne normal düzeyde el yıkama davranışı olduğunu ifade etmiştir. 25 anne çocuğun 20 saniye el yıkama kuralını bilip uyguladığını, 4 anne ise çocuğun 20 saniye kuralını bildiğini ancak uygulamadığını belirtmiştir. 16 anne el yıkama artışını memnun karşıladığını, 6 anne normal karşıladığını, 3 anne obsesyon oluşma kaygısı taşıdığını ve 1 anne de çocuğun paniklemesiden dolayı üzüldügünü belirtmiştir. El yıkama artış sebeplerine bakıldığında; 15 anne virüsten, 11 anne ailede el yıkamanın artmasından, 10 anne yayınlardan, 2 anne aile bilgilendirmesinden ve 2 anne de okulda öğrenmeden kaynaklandığııı belirtmiştir.

Tablo 8: 3-6 Yaş Çocukların Kitle İletişim Araçlarıyla Geçirdiği Zaman

\begin{tabular}{|c|c|c|c|}
\hline & & $\mathrm{f}$ & $\%$ \\
\hline \multirow{3}{*}{$\begin{array}{l}\text { Pandemi } \\
\text { Öncesi }\end{array}$} & Kontrollü kullanım & 24 & 80,00 \\
\hline & Çok sık kullanım & 4 & 13,33 \\
\hline & Hiç kullanmama & 2 & 6,67 \\
\hline Toplam & & 30 & $\% 100$ \\
\hline \multirow{10}{*}{$\begin{array}{l}\text { Pandemi } \\
\text { sonrasi }\end{array}$} & Çok arttı & 21 & 70,00 \\
\hline & Değişiklik yok & 3 & 10,00 \\
\hline & Nadiren kullanım & 3 & 10,00 \\
\hline & Azalma & 2 & 6,67 \\
\hline & $\begin{array}{l}\text { Evde pandemi } \\
\text { yayınları takip etme }\end{array}$ & 15 & 50,00 \\
\hline & $\begin{array}{l}\text { Evde pandemi } \\
\text { yayınları takip } \\
\text { etmeme }\end{array}$ & 14 & 46,67 \\
\hline & $\begin{array}{l}\text { Çocuk pandemi } \\
\text { yayınları izliyor }\end{array}$ & 13 & 43,33 \\
\hline & $\begin{array}{l}\text { Çocuk pandemi } \\
\text { yayınları izlemiyor }\end{array}$ & 13 & 43,33 \\
\hline & $\begin{array}{l}\text { Çocuk pandemi } \\
\text { yayınlarından } \\
\text { etkileniyor }\end{array}$ & 13 & 43,33 \\
\hline & $\begin{array}{l}\text { Çocuk pandemi } \\
\text { yayınlarından } \\
\text { etkilenmiyor }\end{array}$ & 11 & 36,67 \\
\hline
\end{tabular}

Tablo 8'de 3-6 yaş çocukların kitle iletişim araçlarıyla geçirdiği zaman incelendiğinde; pandemi öncesi 24 çocukta kontrollü kullanım olduğu, 4 çocukta fazla kullanım olduğu ve 2 çocukta kullanım olmadığı görülmüsstür. Pandemi sonrasına bakıldığında; kitle iletişim araçları kullanımında 22 çocukta artış olduğu, nadiren kullanan 3 çocuk olduğu, 2 çocukta kullanımda azalma olduğu ve 3 çocukta değişiklik olmadığ1 görülmüştür. Bunun yanısıra 21 anne çocuğun pandemi ile ilgili yayınları takip ettiğini, 8 anne çocuğun yayınları dinlemediğini, 11 anne çocuğun pandemi ile ilgili yayınlardan etkilenmediğini, 13 anne ise çocuğun etkilendiğini belirtirken; 13 anne çocuğun evde pandemi ile ilgili yayınları izlediğini, 13 anne de izlemediğini belirtmiştir. Son olarak 15 anne evde pandemi yayınlarını takip ettiklerini, 14 anne ise pandemi ile ilgili yayınları takip etmediklerini ifade etmiştir. 
Tablo 9: 3-6 Yaş Çocukların Dışarı Çıkma Tutumu

\begin{tabular}{|c|c|c|c|}
\hline & & $\mathrm{f}$ & $\%$ \\
\hline \multirow[t]{2}{*}{$\begin{array}{l}\text { Pandemi } \\
\text { Öncesi }\end{array}$} & $\begin{array}{l}\text { İstekli ve dışarıyı } \\
\text { seviyor }\end{array}$ & 28 & 93,33 \\
\hline & $\begin{array}{l}\text { Dişarı çıkmak } \\
\text { istemiyor }\end{array}$ & 2 & 6,67 \\
\hline \multirow[t]{3}{*}{ Toplam } & & 30 & $\% 100$ \\
\hline & Değişim yok & 1 & 3,33 \\
\hline & Dışarı çıkmak istiyor & 17 & 56,67 \\
\hline \multirow[t]{10}{*}{$\begin{array}{l}\text { Pandemi } \\
\text { sonras1 }\end{array}$} & $\begin{array}{l}\text { Pandemiden sonra } \\
\text { dışarı çıkma } \\
\text { tedirginliği yok }\end{array}$ & 26 & 86,67 \\
\hline & $\begin{array}{l}\text { Sosyal mesafeyi } \\
\text { biliyor ve uyguluyor }\end{array}$ & 20 & 66,67 \\
\hline & $\begin{array}{l}\text { Dışarıda insanları } \\
\text { görünce } \\
\text { öfkeli/üzgün/şaşırmı } \\
\text { ş tepkiler veriyor }\end{array}$ & 13 & 43,33 \\
\hline & $\begin{array}{l}\text { Dışarı çıkmak } \\
\text { istemiyor }\end{array}$ & 12 & 40,00 \\
\hline & $\begin{array}{l}\text { Sosyal mesafeyi } \\
\text { bilmiyor (sürekli } \\
\text { evde olduğundan) }\end{array}$ & 8 & 26,67 \\
\hline & $\begin{array}{l}\text { Dışarıda olanların } \\
\text { hata yaptığını } \\
\text { söylüyor }\end{array}$ & 3 & 10,00 \\
\hline & $\begin{array}{l}\text { Dışarı çıkamadığ } \\
\text { için öfkeleniyor }\end{array}$ & 5 & 16,67 \\
\hline & $\begin{array}{l}\text { İnsanların neden } \\
\text { dışarıda olduklarını } \\
\text { sorguluyor }\end{array}$ & 6 & 20,00 \\
\hline & $\begin{array}{l}\text { Dışarıda insanları } \\
\text { gördükçe çıkmak } \\
\text { istiyor }\end{array}$ & 2 & 6,67 \\
\hline & $\begin{array}{l}\text { Maske ile gezen } \\
\text { insanlara tepki } \\
\text { göstermiyor } \\
\text { Pandemi sonrası } \\
\text { dışarı çıma } \\
\text { tedirginliği var }\end{array}$ & 2 & 10,00 \\
\hline
\end{tabular}

Tablo 9'da 3-6 yaş çocukların dışarı çıkma tutumuna ait veriler yer almaktadır. 28 anne çocuğun pandemi öncesinde dışarı çıkmaya istekli olduğunu ve dışarı çıkmayı sevdiğini, 2 anne ise çocuğun dişarı çıkmaya isteksiz olduğunu belirtmiştir. Pandemi sonrasına bakıldığında; 17 anne çocuğun dişarı/park/bahçeye çıkmak istediğini, 12 anne çocuğun dişarı/park/bahçeye çıkmak istemediğini, 1 anne ise herhangi bir değişim olmadığını belirtmiştir. Diğer veriler incelendiğinde 20 anne çocuğun sosyal mesafeyi bilip uyguladığını, 8 anne bilmediğini belirtirken; 13 anne çocuğun dışarıda insaları görünce öfkeli/üzgün/şaşkın tepkiler verdiğini, 2 anne maskeli gezen insanlara tepki verilmediğini, 3 anne dışarıda gezen insanların hatalı olarak görüldüğünü, 6 anne çocuğun neden dışarıda olmadığına dair sorgulamaya girdiğini, 5 anne çocuğun dışarıda olmadığı için öfkelendiğini, 2 anne ise dışarıda insanları gördükçe çocuğun da dışarı çıkmak istediğini belirtmiştir. Son olarak 26 
anne çocukta pandemi sonrası dışarı çıkma tedirginliği olduğunu, 3 anne ise çocukta pandemi sonrası dışarı çıkma tedirginliği olmadığını belirtmiştir.

Tablo 10: 3-6 Yaş Çocukların Evde Geçirdikleri Zaman

\begin{tabular}{|c|c|c|c|}
\hline & & $\mathrm{f}$ & $\%$ \\
\hline & Normal & 17 & 56,67 \\
\hline $\begin{array}{l}\text { Pandemi } \\
\text { öncesi } \\
\text { birlikte }\end{array}$ & $\mathrm{Az}$ & 11 & 36,67 \\
\hline $\begin{array}{l}\text { geçirilen } \\
\text { zaman }\end{array}$ & Çok & 2 & 6,67 \\
\hline Toplam & & 30 & $\% 100$ \\
\hline & Çok daha az & 1 & 3,33 \\
\hline & $\begin{array}{l}\text { Oyun oynama ve } \\
\text { etkinlik yapmada } \\
\text { artış }\end{array}$ & 28 & 93,33 \\
\hline & $\begin{array}{l}\text { Birlikte geçirilen } \\
\text { zamanda artış }\end{array}$ & 25 & 83,33 \\
\hline $\begin{array}{l}\text { Pandemi } \\
\text { sonrası }\end{array}$ & $\begin{array}{l}\text { Etkinlik ve oyun } \\
\text { tavrında değişim yok }\end{array}$ & 18 & 60,00 \\
\hline & $\begin{array}{l}\text { Oyun ve } \\
\text { etkinliklerde } \\
\text { hastalıktan bahsetme }\end{array}$ & 9 & 30,00 \\
\hline & $\begin{array}{l}\text { Oyun oynama ve } \\
\text { etkinlik yapma daha }\end{array}$ & 2 & 6,67 \\
\hline & $\begin{array}{l}\text { az } \\
\text { Etkinlik ve } \\
\text { oyunlarda daha } \\
\text { agresif }\end{array}$ & 1 & 3,33 \\
\hline
\end{tabular}

Tablo 10'da 3-6 yaş çocukların evde geçirdikleri zaman ile ilgili veriler incelendiğinde; 11 annenin pandemi öncesi az zaman geçirdiği, 17 annenin normal düzeyde zamanda geçirdiği ve 2 annenin çok zaman geçirdiği görülmüştür. Pandemi sonrası ise 25 anne birlikte geçen zamanın arttığını, 28 anne oyun oynama ve etkinlik yapmanın arttığını, 9 anne oyun ve etkinliklerde hastalıklardan bahsedildiğini, 1 anne de oyun ve etkinliklerde daha agresif bir tavır gözlemlediğini belirtmiştir. Bunun yanı sıra 1 anne birlikte geçirilen zamanın azaldığını belirtirken, 2 anne birlikte daha az oyun oynadıklarını ve daha az etkinlik yaptıklarını, 18 anne ise etkinliklerde ve oyun oynama sürecinde herhangi bir değişim olmadığını belirtmiştir.

\section{Tartışma ve Sonuç}

$\mathrm{Bu}$ araştırmada okul öncesi dönem çocuklarının pandemi sürecinde (COVID-19) davranış değişiklikleri ve farkındalık düzeylerinin anne görüşlerine başvurularak incelenmesi amaçlanmıştır. Araştırma sonucunda, çocukların pandemi sonrasında hastalık farkındalıklarının arttığı, çocukların genellikle COVID-19'un ne olduğunu bildikleri, ailelerin genellikle pandemiden sonra çocukları ile süreci konuştukları, çocukların virüsü tehlikeli olarak algıladıkları, virüsün hastalık sebebi olduğunu bildikleri ve farklı şekillerde virüsü yorumladıkları görülmektedir. Çocukların COVID-19 hakkında bu kadar bilgi sahibi olmalarının sebebi Dünya Sağlık Örgütü'nün bu durumu pandemi ilan etmesi, salgının önlenmesi amacıyla ülkemizde birçok tedbir alınması ve çocukların bu tedbirleri ebeveynlerinden, sosyal çevrelerinden, kitle iletişim araçlarından öğrenmeleri olabilir (WHO, 2020). Çocukların devamlı olarak pandemi tedbirlerine maruz kalmaları sürecin çocuklar için tehlikeli bir 
durum olarak algılanmasına sebep olmaktadır. Ailelerin çocuklarıyla süreci konuşmalarının önemine değinen ve araştırma sonucunu destekleyen bir başka araştırma Dalton vd. (2020) tarafından yapılmıştır. Dalton vd. (2020) COVID-19 hakkında etkili iletişim yoluyla çocukların psikolojik sağlı̆̆ının korunması adlı çalışmalarında çocuklar ile COVID-19 hakkında konuşmanın çocukların gereksiz yere korku yaşamalarını engelleyeceğini ifade etmişlerdir.

Araştırma sonucunda annelerin çoğunluğu çocuklarında pandemi öncesinde duygusal ve davranışsal sorunların olmadığını, ancak pandemi sonrasında çocuklarında "kaygı, korku, agresif/öfkeli/saldırgan davranışlar, aşırı hareketlilik, kardeş kıskançlığı, anne-babaya bağımlılık gibi” davranışların ortaya çıktığını belirtmişlerdir. Salgın durumunda çocukların ve ailelerin rutinlerinin bozulması çocuklarda farklı duygusal ve davranışsal sorunların oluşmasına sebep olabilmektedir. Hastalık kavramının çocuk ve ailelerin üzerinde birçok olumsuz etkisi görülmektedir. Bundan dolayı ailelerin bu dönemde süreci daha az stresli geçirmeleri, gerekmedikçe çocuklarıyla pandeminin olumsuzlukları hakkında detaylı konuşmamaları gerekmektedir (Ercan vd., 2020; Er, 2006). Bu araştırmanın sonucunu destekleyen çalışmalara alan yazında rastlanmıştır. Jiao vd. (2020) tarafından gerçekleştirilen COVID-19 salgını sırasında çocuklarda duygusal ve davranışsal bozukluklar adlı çalışmada, çocuklarda COVID-19 sonrasında en fazla görülen bozuklukların içinde çabuk öfkelenme, aileye yapışıp ayrılmama, dikkat dağınıklığı ve soru sormaktan korkma olduğu saptanmıştır. Aynı şekilde Davico vd. (2020) yaptıkları araştırma sonucunda pandemi bölgesindeki çocukların travma sonrası stres bozukluğu açısından risk grubunda olduklarını belirlemişlerdir. Sprang ve Silman (2013) yaptıkları çalışmalarında sağlıkla ilgili bir felakette izole edilen ya da karantinada olan çocukların daha çok travma sonrası stres bozukluğu yaşadıkları sonucuna varmışlardır.

$\mathrm{Bu}$ çalışmada anneler pandemi öncesinde 6 çocukta beslenme sorunu olduğunu belirtmişlerdir ancak pandemi sonrasında düzensiz beslenmenin azaldığı ve genellikle pandemi öncesinde düzenli beslenen çocukların pandemi sonrasında daha çok düzenli beslenmeyi önemsediği görülmüştür. Anneler pandemi sonrasında çocuklarında sağlıklı beslenme algısının oluştuğunu belirtmişlerdir. COVID-19'un bireysel mücadele önlemlerinden birisi de bağışıklık sisteminin güçlendirilmesidir (Aslan, 2020). Ailelerin çocuklarına COVID-19'u anlatmaları, etkilerinden ve nasıl korunacaklarından bahsetmeleri çocukların düzenli beslenmeyi daha çok önemsemelerine sebep olabilir.

Araştırma sonuçlarında, çocukların pandemi sonrasında uyku düzenlerinin çoğunluğunda düzenli olduğu ancak bazı çocuklarda geç uyuyup geç uyanma davranışlarının görüldüğü; çocukların el yıkama alışkanlıklarında pandemi sonrası artış olduğu ve çocukların çoğunluğunun 20 saniye kuralını ellerini yıkarken uyguladığı; annelerin genellikle çocuklarının el yıkama davranışlarından memnun olduğu ancak bazı annelerin çocuklarında obsesyon oluşma kaygısını yaşadığı görülmektedir. Araştırma sonuçları çocukların el yıkama davranışını çoğunlukla virüsten kaynaklı olarak gerçekleştirdiğini göstermektedir. Çocukların uyku düzenlerinin bozulmasının en büyük nedenlerinden biri pandemiden kaynaklı ailelerin evde daha çok zaman geçirmeleri, işlerini uzaktan yürütmeleri ve bundan kaynaklı kendilerinin de geç uyuyup geç kalkması ve anaokuluna giden çocukların okul rutinlerinin olmamasından kaynaklı olabilir. Pandemi kuralları gereğince COVID19 un bulaşma yollarından biri de ellerin temiz yıkanmaması ve ellerin burna ve ağza teması olduğu birçok yayında, kitle iletişim aracında, sosyal medyada devamlı dile getirilmesi, ailelerin çocuklarıyla COVID-19 hakkında konuşmaları, çocukların el yıkamada 20 saniye kuralının bireysel önlemlerle ilgili farkındalıklarının oluşmasının sebepleri arasında sayılabilir (Aslan, 2020).

Araştırma sonucunda annelerin çoğunluğu çocuklarının kitle iletişim araçlarını pandemiden önce kontrollü kullandığını ancak pandemiden sonra kitle iletişim araçlarını kullanmada çok fazla artış olduğunu; ailelerin kendileri kitle iletişim araçlarını kullanırken pandemi ile ilgili yayınları çocuklarının dinlediğini ve bu yayınlardan çocuklarının etkilendiğini ifade etmişlerdir. Araştırmada 
bu sonucun çıkmasının sebebi pandemiden dolayı eğitime ara verilmesi ve uzaktan eğitim sistemleri aracılı̆̆ıyla eğitimin yapılmaya başlanması olabilir. Uzaktan eğitim sistemleriyle yapılan eğitimlere katılabilmek için birçok çocuk ve aile pandemi sonrasında iletişim araçlarını daha fazla kullanmaya başlamış olabilir. Bunun yanı sıra Jiao ve vd. (2020)'nin yaptıkları araştırmada, medyada eğlenceli zaman geçirmenin çocuklarda görülen duygusal ve davranışsal sorunları azaltmada etkili olduğunu belirtmektedirler. Dolayısıyla pandemi sürecinde kitle iletişim araçlarının kullanımının artmasında medyada eğlenceli zaman geçirerek çocukların duygusal ve davranışsal sorunlarının azaltılması amaçlanmış olabilir.

Anneler çocuklarının pandemi sonrasında dışarı çıkma konusunda tedirginlik yaşadıklarını ve genelde sosyal mesafe kuralını bildiklerini; çocukların genellikle balkondan ya da camdan dışarıdaki kişileri gördüklerinde neden dışarda olduklarını sorguladıkları, dışarda olan kişilerin hata yaptığını söyledikleri ve kendisinin dışarda olmamasından kaynaklı öfkelendiğini belirtmiştir. Araştırma sonuçları pandeminin çocukların davranışları ve gelişimleri üzerinde çok fazla olumsuz etkisi olduğunu göstermektedir. Çocukların günlük rutinlerinde yaşanan aksamalar çocukların iyi olma hali ve gelişiminde olumsuz sonuçlar oluşturabilmektedir (The Alliance for Child Protection in Humanitarian Action, 2019). Imran vd. (2020) de yaptıkları çalışmalarında okulların kapatılması ve çocukların arkadaşlarından ayrı kalmasının çocuklarda strese ve endişeye neden olabileceğini belirtmişlerdir.

Araştırma sonucunda anneler; pandemi sonrasında çocuklarıyla geçirdikleri zamanın ve çocuklarıyla birlikte oyun oynama-etkinlik yapma sürelerinin arttığını ifade etmişlerdir. Oyun ve etkinliklerde hastalıktan bahsedildiğini ve bir annenin de etkinliklerde çocuğunun daha agresif olduğunu söylediği sonucuna varılmıştır. Bu sonuçlar değerlendirildiğinde çocukların kreşler ve anaokullarının kapalı olmasından kaynaklı okula gitmemeleri, annelerin uzaktan çalışma sistemine geçmelerinden kaynaklı evde daha çok zaman geçirmeleri çocuklarıyla etkinlik sürelerinin artmasına sebep olduğu söylenebilir.

\section{Öneriler}

-Pandemi sürecinin çocukların davranışları üzerinde olumlu ya da olumsuz sonuçları olmaktadır. Gelecek araştırmalarda çocuklar üzerindeki etkileri farklı değişkenler ele alınarak nitel ve nicel araştırmalarla incelenmesi,

-Normale dönme çalışmalarında çocukların süreçten etkilenme durumlarının değerlendirilmesi ve gerekli psikososyal desteğin sağlanması,

-Eğitimcilerin ve ailelerin bu süreçte çocukların salgın sürecindeki tepkilerini iyi gözlemeleri, stres ve kaygıyı azaltmaya yönelik olumlu tutum sergilemeleri ve olumlu yönde bir odaklanma ve motivasyon konusunda model olmaları,

-Pandeminin aileler ve çocuklar üzerindeki olumsuz etkileri düşünülerek psikososyal hizmet çalışmalarının ön plana çıkarılması önerilmektedir.

\section{Kaynakça}

Aslan, R. (2020). Tarihten Günümüze Epidemiler, Pandemiler ve Covid- 19. Ayrıntı Dergisi, 8(85), $35-41$.

Büyüköztürk, Ş., Kılıç, Çakmak, E., Akgün, ÖE., Karadeniz, Ş., Demirel, F. (2019). Eğitimde Bilimsel Araştırma Yöntemleri. Pegem Yayınları.

Dalton, L., Rapa, E. \& Stein, A. (2020). Protecting The Psychological Health Of Children Through Effective Communication About COVID-19. www.thelancet.com/childadolescent, https://doi.org/10.1016/S2352-4642(20)30097-3 
Davico, C., Ghiggia, A., Marcotulli, M.D., Ricci, F., Amianto, F. \& Vitiello, B. (2020). Psychological impact of the COVID-19 pandemic on adults and their children in Italy. The Lancet Psychiatry. https://papers.ssrn.com/sol3/papers.cfm?abstract_id=3576933. http://dx.doi.org/10.2139/ssrn.3576933

Dawson, C. (2009). Introduction to research methods: A practical guide for anyone undertaking a research project. How to Books Ltd.

Dong, Y., Mo, X., Hu, Y., et al. (2020). Epidemiological characteristics of 2143 pediatric patients with 2019 coronavirus disease in China. Pediatrics. http://dx.doi.org/10.1542/peds.20200702 .

Er, M. (2006). Çocuk, hastalık, anne-babalar ve kardeşler. Çocuk Sağllğg ve Hastalıkları Dergisi, 49, 155-168.

Ercan, S., Arman, A.R., İnal Emiroğlu, N., Öztop, D.B. \& Yalçın, Ö. (2020). Türkiye Çocuk ve Genç Psikiyatrisi Derneği Covıd-19 (Korona) Virüs Salgını Sırasında Aile, Çocuk ve Ergenlere Yönelik Psikososyal Ve Ruhsal Destek Rehberi. Ankara Üniversitesi. https://www.ankara.edu.tr/wp-content/uploads/sites/6/2020/03/cogepdercovid19rehberi30mart2020.pdf.pdf

Gander, M.J. \& Gardıner. HW. (2015). Çocuk Ve Ergen Gelişimi. Onur, B. (Ed.) Dönmez, A. Çelen, HN. (Çev.), İmge Yayınları.

Imran, N., Zeshan M, Pervaiz Z. (2020). Mental health considerations for children \& adolescents in COVID-19 Pandemic. Pak J. Med Sci. 2020;36(COVID19 S4):COVID19-S67-S72. https://doi.org/10.12669/pjms.36.COVID19-S4.2759

Jiao, W.Y., Wang, L.N., Liu, J., Fang, S.F., Jiao, F.Y., Pettoello Mantovani, M. \& Somekh, E. (2020). Behavioral and Emotional Disorders in Children during the COVID-19 Epidemic. The Journal of Pediatrics. Basimda.

Johnson, B., Chrıstensen L. (2014). Eğitim Araştırmaları Nicel, Nitel ve Karma Yaklaşımlar. Budak, İ. Burdak, A. (Çev.). 4. Baskıdan Çeviri. Eğiten Kitap.

Okumuş, A. (2020). Bilimsel Araştırma Teknikleri. İstanbul. İstanbul üniversitesi yayınları. E-kitap: 107. https://yokdersleri.yok.gov.tr/\#ders

Piaget, J. (2019). Çocuğun Gözüyle Dünya. (Çev. Yergüz, İ.) Dost Yayınevi.

Sinha, IP., Harwood, R., Semple, MG., Hawcutt, DB., Thursfield, R., Narayan, O., et al. (2020). COVID-19 infection in children. Lancet Respir Med. http://dx.doi.org/10.1016/s22132600(20)30152-1

Sprang, G. \& Silman, M. (2013). Post Traumatic Stress Disorder İn Parents And Youth After Health Related Disasters. Disaster Medicine And Public Health Preparation. 7(1). 105-110. http://dx.doi.org/10.1017/dmp.2013.22

The Alliance for Child Protection in Humanitarian Action (2019). Teknik Bilgi Notu: Koronavirüs Pandemisi Sırasında Çocukların Korunması, 1. Baskı, Mart.

Türk Dil Kurumu, Bilim ve Sanat Terimleri Sözlüğü. https://sozluk.gov.tr/

Yıldırım, A., Şimşek H. (2018). Sosyal Bilimlerde Nitel Araştırma Yöntemleri. Seçkin yayıncılık.

Wagner, KD. (2020). Addressing the Experience of Children and Adolescents During the COVID19 Pandemic. J Clin Psikiyatrisi. $81 \quad$ (3): $20 \mathrm{ed} 13394$. http://dx.doi.org/10.4088/JCP.20ed13394 
WHO (2020) http://www.euro.who.int/en/health-topics/health-emergencies/coronavirus-covid-19

WHO (2020) https://www.who.int/news-room/q-a-detail/q-a-coronaviruses.

Witt, A., Ordóñez, A., Martin, A. et al. (2020). Child and adolescent mental health service provision and research during the Covid-19 pandemic: challenges, opportunities, and a call for submissions. Child Adolesc Psychiatry Ment Health, 14(19), https://doi.org/10.1186/s13034-020-00324-8 